\title{
Heavy Metal Contamination and Potential Ecological Risks in Surface Sediments along Dar es Salaam Harbour Channel
}

\author{
Benard Mwakisunga $^{1 *}$, Harishchandra B. Pratap ${ }^{1}$, John F. Machiwa ${ }^{2}$ and Flora Stephano ${ }^{1}$ \\ ${ }^{I}$ Department of Zoology and Wildlife Conservation, University of Dar es Salaam, Tanzania. \\ ${ }^{2}$ Department of Aquatic Sciences and Fisheries Technology, University of Dar es Salaam, \\ Tanzania. \\ *Corresponding author. E-mail addresses: sunga2008@gmail.com, pratap@udsm.ac.tz, \\ jmachiwa@udsm.ac.tz,fsnyaki@udsm.ac.tz
}

Received 16 Mar 2021, Revised 14 Oct 2021, Accepted 23 Oct 2021, Published Dec 2021

DOI: https://dx.doi.org/10.4314/tjs.v47i5.11

\begin{abstract}
Investigation of heavy metal contamination along Dar es Salaam harbour channel was carried out in order to determine their current concentrations, sources and potential ecological risks to benthic biota. Sampling was carried out from January to May 2019 and samples analysed using ICP-OES and C-H-N-S analyser. Analysis of heavy metal relationships showed that, $\mathrm{Cu}, \mathrm{Zn}, \mathrm{Cr}$, $\mathrm{As}, \mathrm{Ni}, \mathrm{Co}, \mathrm{Fe}, \mathrm{Cd}$ had strong relationships with each other, while $\mathrm{Pb}$ only related to $\mathrm{Zn}$. Principal component analysis partitioned metals into two groups; $\mathrm{PC} 1: \mathrm{Ni}, \mathrm{Cr}, \mathrm{Fe}, \mathrm{Co}, \mathrm{As}, \mathrm{Cu}$, $\mathrm{Cd}$, and $\mathrm{Zn}$ explaining $73.6 \%$ variance and $\mathrm{PC} 2: \mathrm{Pb}, \mathrm{Zn}$, and $\mathrm{Cd}$ with $13.7 \%$ variance. Similarly, $\mathrm{Cd}, \mathrm{Pb}$ and $\mathrm{Zn}$ had severe to very high enrichments $(\mathrm{Cd}>\mathrm{Pb}>\mathrm{Zn})$ showing serious anthropogenic contamination of these metals in sediments along Dar es Salaam harbour channel. Degree of contamination and potential ecological risks varied from low, moderate, to high; indicating that sediments were considerably contaminated with heavy metals. Levels of contamination varied in space and according to the type of heavy metal Higher contamination and ecological risks were revealed at the harbour area probably due to the observed high concentrations of $\mathrm{Cd}, \mathrm{Pb}$ and $\mathrm{Zn}$. Monitoring of metals should be emphasized in order to control contaminants release into this area from their sources.
\end{abstract}

Keywords: Dar es Salaam harbour channel, Heavy metals, Contamination, Sediments, Degree of contamination, Ecological risks.

\section{Introduction}

Heavy metals contamination in sediments has been a growing challenge in Tanzania, mostly in the coastal marine waters which receive urban effluents. The main sources of heavy metals are from industrial, municipal and agricultural discharges. Heavy metals are among the most persistent pollutants in ecosystems due to their resistance to decomposition in natural conditions (Soliman et al. 2015, Mihale 2019). In sediments, metals accumulate up to concentrations above the background levels (Bai et al. 2011, Mahugija and Sheikh 2018), making sediments to be more toxic than the overlying water (Sivakumar et al. 2016, Mahugija and Sheikh 2018), and thus posing potential hazardous environment to benthic ecosystems. They either cause direct toxicity to benthic organisms or become a source of contaminants for bioaccumulation in the food chains (EPA 2002, den Besten and Munawar 2005). Some heavy metals (e.g., Fe, $\mathrm{Zn}, \mathrm{Cu}$, and $\mathrm{Mn}$ ), however are essential, playing important roles in biological systems (Hogstand and Haux 1991), but become toxic at higher concentrations (Soliman et al. 2015, Custodio et al. 2019). Non-essential metals 
such as $\mathrm{Pb}$ and $\mathrm{Cd}$ are usually potent toxins even at relatively low concentrations (Lee et al. 2019). Hence, accumulation of heavy metals in sediments threatens the survival and fitness of benthic ecosystems and increases stress and damage to aquatic systems.

Despite the alarming heavy metal contamination in coastal waters of Tanzania (Machiwa 2010, Mihale 2017), the information on heavy metal pollution status, extent of contamination and its ecological risks using pollution assessment indices are scarcely available. Pollution assessment indices are useful techniques for the comprehensive assessment of contamination in sediments and forecast the forthcoming negative impacts of contaminants to ecosystems (Kowalska et al. 2018), thus their applications in this study emphasized on the extent of heavy metal contamination along the harbour channel. The pioneer study for the assessment of the status of heavy metal contamination in sediments using pollution indices in Tanzania and the Western Indian Ocean was conducted by Mihale (2019) along Mtoni estuary, upstream of Dar es Salaam harbour channel. The observed heavy metals contamination in sediments along Mtoni estuary varied from moderate to considerable ecological risks.

This study aimed at assessing the metal contamination and potential ecological risks in surface sediments along Dar es Salaam harbour channel which is the main effluent receiving area along the coast. The established contamination status offers prerequisite information for pollution control and formulation of monitoring guidelines in Tanzania and the Western Indian Ocean region.

\section{Materials and Methods \\ Description of the study area}

Dar es Salaam is located between latitudes $6^{\circ} 27^{\prime}$ and $7^{\circ} 15^{\prime} \mathrm{S}$ and longitudes $39^{\circ}$ and $39^{\circ} 33^{\prime} \mathrm{E}$, extending about $100 \mathrm{~km}$ from Mpiji River in the north to Mzinga River in the south (Machiwa 2010). Dar es Salaam harbour channel is located in a sheltered inlet of a narrow bay protected from free seawater flushing (Figure 1). In this study harbour area is the area at the ship loading and off-loading area, while harbour channel includes the southern and northern parts of the harbour area.

The predominant water movements are tidal and seawater waves which influence the direction of localized inshore currents and fluvial flows from Mtoni and Msimbazi estuaries. These forces in turn govern the deposition and distribution of sediments in the harbour channel (Machiwa 2000). The study focused on Dar es Salaam harbour channel which is a recipient of the main rivers in Dar es Salaam City, including Mzinga, Kizinga and Msimbazi rivers, associated with port and shipping operation activities.

\section{Sample collection}

Sampling campaigns were conducted from January to May, 2019 at Dar es Salaam harbour channel. Prior to sampling, a thorough survey was conducted to establish sampling stations using Global Positioning System based on the types of sediments and areal coverage of the harbour channel so as to acquire representative samples of the area. Sediment sampling was conducted according to the methods developed by EPA (2002) and Goh et al. (2014). Sediment sampling was conducted along the harbour channel from the southern part of the harbour near Mwalimu Nyerere bridge, at the harbour area and northern part of the harbour at the ship anchorage before offloading. A total of thirtyfive (35) sampling stations were established, and at each station, three sediment samples were collected at $0-50 \mathrm{~cm}$ depth using a 50 $\mathrm{cm}$ piston gravity plastic corer. Samples were then kept in zip lock plastic bags, labelled, sealed and stored in a cool box containing ice blocks. Samples were then transported to the laboratory, kept in a refrigerator at $4{ }^{\circ} \mathrm{C}$ until analysis. 


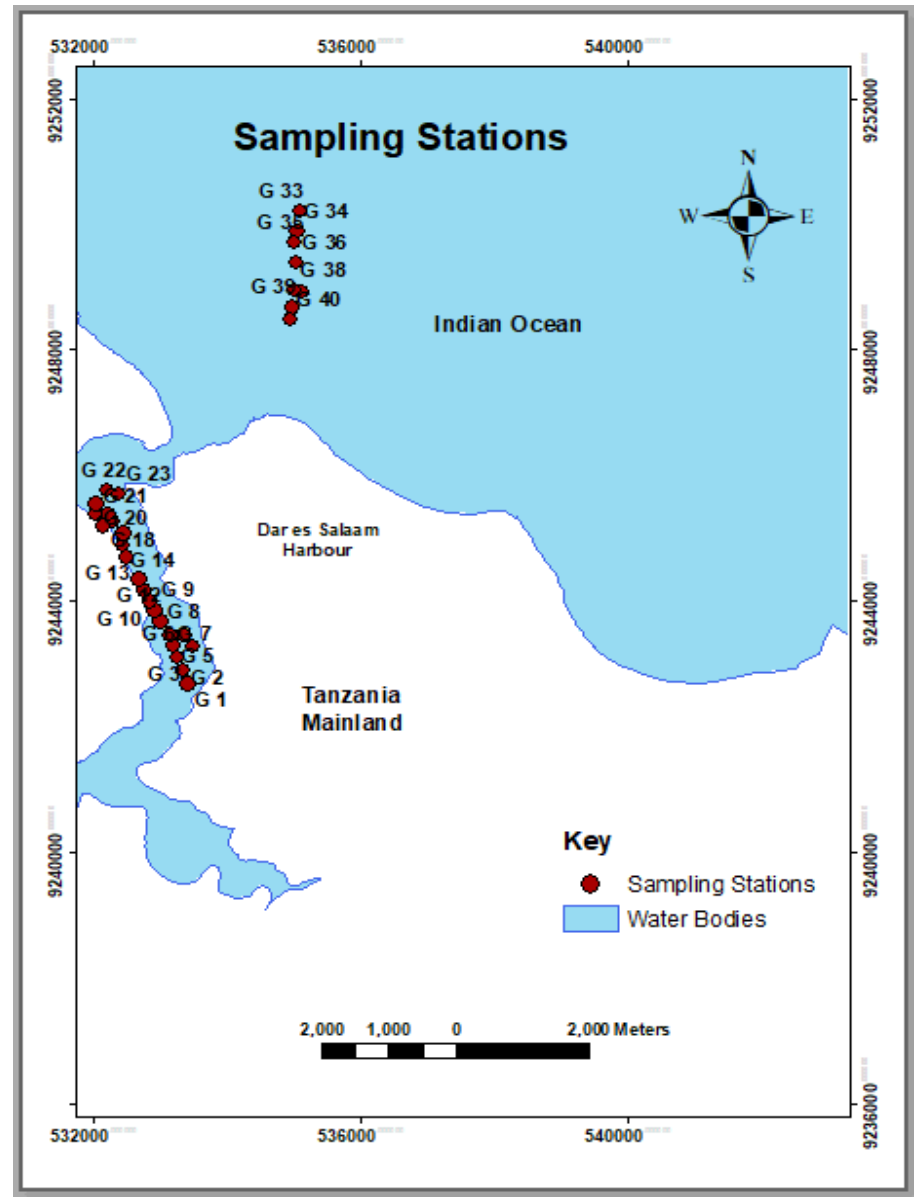

Figure 1: Map showing the sampling stations.

Heavy metals analysis and determination of total nitrogen and total organic carbon in sediments

Analysis of heavy metals followed EPA (2018), Hazardous Waste Test Methods/SW846 Method 6010D for Inductively Coupled Plasma-Optical Emission Spectrometry (ICPOES). Sediment samples were air dried for two days and grinded using mortar and pestle. About $1 \mathrm{~g}$ of the sediment sample was weighed and placed into Kjeldahl tubes, thereafter $10 \mathrm{ml}$ of aqua-regia $(\mathrm{HCl}$ and $\mathrm{HNO}_{3} ; 3: 1$ mixture) was added. The mixture was digested under Kjeldahl system (TR Gerhardt No.4021853) for two hours at 180 ${ }^{\circ} \mathrm{C}$. Samples were allowed to cool to room temperature, and then filtered using Whatman filter paper no 41 into $100 \mathrm{ml}$ volumetric flasks and filled up to the mark with deionized water. Heavy metals were analysed at the Government Chemist Laboratory Authority using ICP-OES (Thermo Scientific Icap 6000 series). Determination of total nitrogen and total organic carbon in sediments were carried out at the Nelson Mandela African Institution of Science and Technology. Samples were dried at $60{ }^{\circ} \mathrm{C}$ in an oven, a portion was grinded to fine powder using a porcelain mortar and pestle, homogenized and paced in an aluminium pan dried at $105{ }^{\circ} \mathrm{C}$. After cooling, about $0.35 \mathrm{~g}$ of each sample was digested by addition of potassium dichromate and sulphuric acid, cooled and before addition of water to stop the reaction, phosphoric acid was added drop by drop until bubbling stopped in order to remove interferences from ferric ions and carbonates present in the sample. Wet samples were then oven dried at $40{ }^{\circ} \mathrm{C}$ for 24 hours and 
then at $105{ }^{\circ} \mathrm{C}$ for 30 minutes for complete digestion of organic matter. Thereafter, the samples were placed in C-H-N-S analyser for analysis.

\section{Quality control}

Quality control included triplicate sampling of sediments and analysis, procedural blanks, and measurement of the Certified Reference Materials (IAEA-356) which were treated in the similar manner like the samples. Blank analysis was also used to monitor the precision of analysis in which results were blank corrected using respective mean blank concentrations before determination of the concentrations of each heavy metal and the reference. Precision of ICP-OES analysis was better than $5 \%$ relative standard deviation (RSD). The limits of detection of each heavy metal were set at three times of the standard deviation of the mean signal from the procedural blanks. The detection limits of each metal were as in Table 1.

The percentage recoveries of the measured metals based on the mean values compared to the certified reference materials ranged from $81.23 \%$ to $97.18 \%$ and RSD ranged from 4.11 to $10.36 \%$ (Table 2). The values were under the recommended limits of $80-120 \%$ for reference samples and $\leq 15 \%$ RSD (Addis and Abebaw 2017). The results indicated good agreement between the certified and the obtained values.

\section{Data Analysis}

\section{Data analysis using pollution indices}

Data were subjected to multivariate analysis using IBM SPSS Statistics ver. 25 software package through Pearson correlation matrix, principal component analysis through varimax rotation with eigenvalues $>1$ using Kaiser normalization to assess the relationships between metals and the distinction between groups of heavy metals. Pearson correlation and principal component analysis were considered significant when the correlation coefficients were greater than 0.05 $(\alpha=0.05)$ and eigenvalues greater than 1 , respectively.

Table 1: Detection limits $(\mu \mathrm{g} / \mathrm{g})$ of the analyzed metals

\begin{tabular}{cccc} 
Metal & Detection limit & Metal & Detection limit \\
$\mathrm{As}$ & 0.004 & $\mathrm{Cu}$ & 0.002 \\
$\mathrm{Cd}$ & 0.0003 & $\mathrm{Fe}$ & 0.9 \\
$\mathrm{Co}$ & 0.0005 & $\mathrm{Ni}$ & 0.003 \\
$\mathrm{Cr}$ & 0.005 & $\mathrm{~Pb}$ & 0.002 \\
& & $\mathrm{Zn}$ & 0.02 \\
\hline
\end{tabular}

Table 2: Recovery and precision test results for the laboratory reference samples

\begin{tabular}{ccccc}
\hline Metal & $\begin{array}{c}\text { Reference value } \\
(\mathrm{mg} / \mathrm{g})\end{array}$ & $\begin{array}{c}\text { Obtained value } \\
(\mathrm{mg} / \mathrm{g})\end{array}$ & Recovery $(\%)$ & RSD \\
\hline $\mathrm{Cu}$ & 43 & $39.24 \pm 1.57$ & $91.26 \pm 5.13$ & 5.62 \\
$\mathrm{Zn}$ & 100 & $97.18 \pm 2.11$ & $97.18 \pm 6.18$ & 6.36 \\
$\mathrm{~Pb}$ & 100 & $93.69 \pm 1.16$ & $93.69 \pm 3.85$ & 4.11 \\
$\mathrm{Cr}$ & 56 & $50.05 \pm 1.22$ & $90.16 \pm 4.18$ & 5.52 \\
$\mathrm{Cd}$ & 2 & $1.8 \pm 0.68$ & $94.43 \pm 7.23$ & 7.66 \\
$\mathrm{As}$ & 25 & $23.03 \pm 0.65$ & $92.12 \pm 6.22$ & 5.11 \\
$\mathrm{Ni}$ & 20 & $18.13 \pm 2.14$ & $90.66 \pm 9.40$ & 10.36 \\
$\mathrm{Co}$ & 5 & $4.06 \pm 0.87$ & $81.23 \pm 7.10$ & 7.87 \\
$\mathrm{Fe}$ & 400 & $366.16 \pm 0.85$ & $91.54 \pm 4.22$ & 4.61 \\
\hline
\end{tabular}

Varimax values greater than 0.75 were considered strong significant correlations, $0.75-0.5$ moderate and $0.50-0.30$ low (Liu et al. 2003). Hierarchical cluster analysis (HCA) through squared Eucledian distances was used to establish the relationships between heavy 
metals and their sources in sediments. Paired Student t-test was used to compare contaminants concentrations between sampling stations and the harbour area.

Potential ecological risks of heavy metal contamination were assessed using various pollution indices, including enrichment factor (EF) normalized by iron, since iron has a wide distribution in the Earth's crust (Saleh et al. 2018). EF was used to determine the anthropogenic influence on heavy metals contamination in sediments. Contamination factor (CF) was used to assess the degree of heavy metal contamination in sediments while classification of degree of contamination was conducted using geoaccumulation index (Igeo) (Adeyemi et al. 2019, Krampah et al. 2019).

\section{Enrichment Factor (EF)}

The coefficients of enrichment were determined using average concentrations of metals in the Earth's crust established by Turekian and Wedepohl (1961) and expressed as:

$$
E F=\frac{\left(\frac{C m}{C F e}\right) \text { sample }}{\left(\frac{C m}{C F e}\right) \text { background }}
$$

where, $(\mathrm{Cm} / \mathrm{CFe})$ sample is the ratio of concentration of heavy metal of interest and iron in the sample; $(\mathrm{Cm} / \mathrm{CFe})$ background is the ratio of heavy metal of interest and iron in the background rock (Adeyemi et al. 2019).

The contamination categories were recognized on the basis of the enrichment factor as follows: $E F<2$ Deficiency to minimal enrichment, $\mathrm{EF}=2-5$ Moderate enrichment, $\mathrm{EF}=5-20$ Severe enrichment, $\mathrm{EF}=20-40$ Very high enrichment and $\mathrm{EF}>$ 40 extremely high enrichment.

\section{Contamination factor $(\mathrm{CF})$}

Contamination factor $(\mathrm{CF})$ is the ratio between the concentration of heavy metal in the sample to that in the background, expressed as:

$$
C F=\frac{(\text { Cmetal }) \text { sample }}{(\text { Cmetal }) \text { background }}
$$

where, (Cmetal)sample is the concentration of a metal in sample;

(Cmetal)background is the average concentration of a metal in a shale background in the Earth's crust (Adeyemi et al. 2019).

Contamination status is categorized into 6 categories; $\mathrm{CF}<1$ is low contamination; $1 \leq$ $\mathrm{CF} \leq 3$ is moderate contamination; $3 \leq \mathrm{CF} \leq 6$ is considerable contamination; and $\mathrm{CF} \leq 6$ is very high contamination.

\section{Geo-Accumulation Index (Igeo)}

Igeo is expressed as:

$$
\text { Igeo }=\log 2\left(\frac{\text { Cn sample })}{1.5 * \text { Bn background })}\right)
$$

Where, $\mathrm{Cn}$ is the measured concentration of heavy metal in the sample, $\mathrm{Bn}$ is the average shale value, and 1.5 is the factor compensating the background data (correction factor) due to lithogenic effects (Sana'a 2015).

\section{Degree of contamination (CD)}

Is the sum of contamination factors for a given study area expressed as:

$$
D C=\sum_{i=1}^{n} C F
$$

Measures the degree of overall contamination in surface layers in a particular sediment sample or sampling site (Sivakumar et al. 2016). It is classified as; CD $<6$ low degree of contamination; $6<\mathrm{CD}<12$ moderate degree of contamination; $12<\mathrm{CD}<24$ considerable degree of contamination; and $\mathrm{CD}>24$ high degree of contamination.

\section{Potential Ecological Risk Coefficient (PERC)}

This is the multiplication of CF of each heavy metal and toxicological response factor (Tr) of individual heavy metals. According to Soliman et al (2015), it is calculated as;

$$
P E R C=C F_{n} x T_{r}
$$

Where, $\mathrm{CF}_{\mathrm{n}}$ and $\mathrm{T}_{\mathrm{r}}$ are the contamination factor and toxic response factor of individual heavy metals, respectively. According to Hakanson (1980), toxic response factor is established based on abundance principle by calculating potential biotoxicity from heavy metal abundances in a medium of interest like sediments, water etc and the sink factor which is the ratio of natural background concentrations of heavy metals and preindustrial reference values for sediments. 
The toxic response factors for heavy metals $\mathrm{Pb}, \mathrm{Cd}, \mathrm{Cr}, \mathrm{Cu}, \mathrm{Zn}, \mathrm{Ni}, \mathrm{As}$ and $\mathrm{Mn}$ are 5, 30, 2, 5, 1, 5, 1 and 10, respectively (Darko et al. 2017) and the potential ecological risk coefficient categories are PERC $\leq 40$ low ecological risk, $40<$ PERC $\leq 80$ moderate ecological risk; $80<$ PERC $\leq 160$ appreciable ecological risk; $160<$ PERC $\leq 320$ high ecological risk; and > 320 serious ecological risk (Soliman et al. 2015, Keshavarzi and Kumar 2020).

\section{Potential Ecological Risk Index (PERI)}

It is the sum of potential ecological risks coefficients of each metal (Er) expressed as:

$$
P E R I=\sum_{i=1}^{n} E r
$$

where $\mathrm{Er}=$ potential ecological risk coefficient.

The risks are categorized as PERI $<150$ low ecological risk, $150<$ PERI < 300 moderate ecological risk, $300<$ PERI < 600 high ecological risk and PERI $\geq 600$ significantly high ecological risk.

\section{Results and Discussion \\ Heavy metals total concentrations in sediments}

Heavy metal concentrations in the surface sediments $(0-50 \mathrm{~cm})$ at Dar es Salaam harbour channel varied significantly between metals and with sampling stations. Copper concentrations ranged from 2.32 to 76.60 $\mathrm{mg} / \mathrm{kg}$ with an average of $18.24 \mathrm{mg} / \mathrm{kg}$. Lead concentrations ranged from 0.20 to 208.47 $\mathrm{mg} / \mathrm{kg}$ and the average was $27.51 \mathrm{mg} / \mathrm{kg}$, with highest concentrations at the harbour area. Cadmium concentrations ranged from 0.15 to $5.79 \mathrm{mg} / \mathrm{kg}$ with average value of $1.75 \mathrm{mg} / \mathrm{kg}$. High concentrations of $\mathrm{Cd}$ were observed in the southern part of the harbour with a gradual decrease to the north away from the harbour. Zinc concentrations ranged from 3.91 to $188.29 \mathrm{mg} / \mathrm{kg}$ and averaged at 54.51 $\mathrm{mg} / \mathrm{kg}$.

Chromium concentrations ranged from 6.66 to $72.45 \mathrm{mg} / \mathrm{kg}$ with an average value of $34.75 \mathrm{mg} / \mathrm{kg}$. The harbour area had higher concentration of $\mathrm{Cr}$ relative to the channel area. Arsenic concentrations ranged from 0.93 to $15.8 \mathrm{mg} / \mathrm{kg}$ with an average value of 7.32 $\mathrm{mg} / \mathrm{kg}$, and showed high concentrations in the southern part of the harbour. The mean concentration of As was relatively higher in southern part of the harbour area than at the harbour. Nickel concentrations ranged from 0.20 to $20.36 \mathrm{mg} / \mathrm{kg}$ and the average was 8.80 $\mathrm{mg} / \mathrm{kg}$. However, concentrations of $\mathrm{Ni}$ were relatively low throughout the channel compared to other metals and the recommended targets

Mean concentrations of the heavy metals were compared in the harbour channel (sites GC1 - 9 and GC 31-40) and with those at the harbour area (sampling sites GC-10-30) as well as the established environmental quality targets. The mean concentrations of $\mathrm{Cu}, \mathrm{Pb}$, $\mathrm{Cr}$ and $\mathrm{Zn}$ at the harbour area were relatively higher than those in the channel, indicating additional inputs from anthropogenic activities at the harbour area. $\mathrm{Cu}, \mathrm{Zn}, \mathrm{Cr}$ and As concentrations were within the range of the concentrations reported in previous studies (Machiwa 2010, Mrutu et al. 2013, Kowalska et al. 2018). Mean concentrations of $\mathrm{Pb}$ and $\mathrm{Cd}$ were above the average shale concentrations in the Earth's crust (Turekian and Wedepohl 1961), threshold effect levels (Environment Canada 1994), Florida no effect level (MacDonald 1993) and WIO Environmental quality targets (UNEP and CSIR 2009), indicating higher $\mathrm{Pb}$ and $\mathrm{Cd}$ contamination along Dar es Salaam harbour channel (Table 3).

Similarly, Machiwa (2010) and Mihale (2017) observed high concentrations of $\mathrm{Cu}$ and $\mathrm{Cd}$ in Mtoni creek upstream of the harbour channel, suggesting that they originate from anthropogenic activities in the City. High concentration of $\mathrm{Pb}$ in samples from the harbour area implied that its main sources were from anthropogenic activities at the harbour area. High As levels over the environmental quality targets in the southern part of the harbour was due to the presence of fine sediments in the area which coats with iron and manganese hydroxy-oxides forming complexes with As (Machiwa 2010). The concentrations of $\mathrm{Ni}$ were below all the recommended environmental quality targets, despite the fact that $\mathrm{Ni}$ and $\mathrm{Pb}$ are among the elements found in petroleum products, 
lubricants and marine diesel oil (Mihale 2017, 2019). This indicated that low Ni was due to low carbon content in sediments to complex more Ni (Mrutu et al. 2013, Silva et al. 2019). However, the overall trend of heavy metal distribution was decreasing offshore, a trend similar to that observed by Mrutu et al. (2013), Mihale (2017), and Silva et al. (2019), associated with the changes in sediment grain size from clay-silt to sandy-pebble offshore (Mwakisunga et al. 2020).

\section{Sources of heavy metals in surface sediments along Dar es Salaam Harbour channel}

Pearson correlation (Table 4) and Principal component matrix (Table 5, Figure 2), partitioned heavy metals in two groups; PC1: Ni, Cr, Fe, Co, As, Cu, Cd and $\mathrm{Zn}$ explaining $73.6 \%$ of the variance, $\mathrm{PC} 2: \mathrm{Pb}$, $\mathrm{Zn}$ and $\mathrm{Cd}$ explaining $13.7 \%$ of the variance. However, $\mathrm{Cd}$ had moderate significant correlation in both groups in varimax rotation. Hierarchical cluster analysis using agglomerative clustering and dendrogram method (Figure 3) grouped heavy metals into two groups, group I comprised of As, $\mathrm{Co}, \mathrm{Ni}$, $\mathrm{Cu}, \mathrm{Cr}, \mathrm{Pb}, \mathrm{Zn}, \mathrm{Mn}$, and $\mathrm{Cd}$, and group II contained Fe (Figure 3a). However, further clustering in absence of $\mathrm{Fe}$, three groups were classified, group I: $\mathrm{As}, \mathrm{Co}, \mathrm{Ni}$, and $\mathrm{Cd}$, group II: $\mathrm{Cu}, \mathrm{Cr}$, and $\mathrm{Pb}$, and group III was $\mathrm{Zn}$.

Heavy metals in each group (i.e., $\mathrm{PC} 1$ and PC2) indicated close relationship to each other signifying similar sources. However, Zn and $\mathrm{Cd}$ had significant values in both PC1 and $\mathrm{PC} 2$ in rotated component matrix, while $\mathrm{Pb}$ only correlated with $\mathrm{Zn}$ (Table 2), thus indicating that heavy metals in the two groups had similar sources. Hierarchical Cluster Analysis (HCA) in presence of iron showed that group I (As, $\mathrm{Co}, \mathrm{Ni}, \mathrm{Cu}, \mathrm{Cr}, \mathrm{Pb}, \mathrm{Zn}, \mathrm{Mn}$, and $\mathrm{Cd}$ ) heavy metals were from anthropogenic sources, while group II (i.e. $\mathrm{Fe}$ ) was from natural lithogenic processes. Furthermore, HCA in absence of $\mathrm{Fe}$ to investigate different sources of anthropogenic origins of heavy metals, showed three groups of similar sources (Figure 3b). Group I (As, $\mathrm{Co}, \mathrm{Ni}$, and $\mathrm{Cd}$ ) metals were higher in the southern part of the harbour than at the harbour area and northern part of the harbour, indicating their fluvial origin from Mtoni estuary upstream, with the main sources from industrial, sewage and agricultural activities in the City (Silva et al. 2016, Mihale 2017). On the other hand, group II $(\mathrm{Cu}, \mathrm{Cr}$ and $\mathrm{Pb})$ corresponded with their high concentrations at the harbour area, thus indicating its predominant origin at the harbour area probably due to ship operations, maintenances, atmospheric deposition and local non-point sewage inputs from harbour surroundings. Likewise, group III (Zn) was largely from local non-point battery sources (Mihale 2017, Al-Edresy et al. 2019, Silva et al. 2019).

Table 3: Comparison of mean heavy metal levels (mg/dw) along Dar es Salaam harbour channel with the established environmental quality targets $(n=35)$

\begin{tabular}{llllll}
\hline Metal & This study & $\begin{array}{l}\text { Threshold } \\
\text { effect level }\end{array}$ & $\begin{array}{l}\text { Florida } \\
\text { Effect level }\end{array}$ & EQTs & $\begin{array}{l}\text { Average shale } \\
\text { concentration }\end{array}$ \\
\hline $\mathrm{Cu}$ & $32.1 \pm 13.8$ & 18.7 & 28.0 & 18.7 & 45.0 \\
$\mathrm{Zn}$ & $105.6 \pm 43.5$ & 124 & 68.0 & 124 & 95 \\
$\mathrm{~Pb}$ & $42.5 \pm 20.9$ & 30.2 & 21.0 & 30.2 & 20 \\
$\mathrm{Cr}$ & $57.2 \pm 16.6$ & 52.3 & 33.0 & 52.3 & 90 \\
$\mathrm{Cd}$ & $2.4 \pm 0.8$ & 0.68 & 1.0 & 0.68 & 0.3 \\
$\mathrm{As}$ & $10.8 \pm 2.5$ & 7.24 & 8.0 & 7.24 & 13 \\
$\mathrm{Ni}$ & $13.5 \pm 5.1$ & 15.9 & & 15.9 & 68 \\
\hline
\end{tabular}


Table 4: Spearman correlation coefficients of heavy metals $(n=27, \alpha=0.05)$

\begin{tabular}{|c|c|c|c|c|c|c|c|c|c|}
\hline & $\mathrm{Cu}$ & $\mathrm{Zn}$ & $\mathrm{Pb}$ & $\mathrm{Cr}$ & $\mathrm{Cd}$ & As & $\mathrm{Ni}$ & Co & $\mathrm{Fe}$ \\
\hline $\mathrm{Cu}$ & 1 & 0.722 & 0.321 & 0.839 & 0.449 & 0.702 & 0.842 & 0.872 & 0.843 \\
\hline $\mathrm{Zn}$ & & 1 & 0.796 & 0.701 & 0.513 & 0.643 & 0.677 & 0.679 & 0.710 \\
\hline $\mathrm{Pb}$ & & & 1 & 0.280 & 0.465 & 0.457 & 0.274 & 0.214 & 0.310 \\
\hline $\mathrm{Cr}$ & & & & 1 & 0.593 & 0.832 & 0.961 & 0.928 & 0.984 \\
\hline $\mathrm{Cd}$ & & & & & 1 & 0.703 & 0.644 & 0.557 & 0.630 \\
\hline As & & & & & & 1 & 0.856 & 0.769 & 0.875 \\
\hline $\mathrm{Ni}$ & & & & & & & 1 & 0.965 & 0.974 \\
\hline Co & & & & & & & & 1 & 0.949 \\
\hline $\mathrm{Fe}$ & & & & & & & & & 1 \\
\hline
\end{tabular}

Table 5: Principal components of heavy metals in sediments of Dar es Salaam Harbour channel total variance explained

\begin{tabular}{ccccc}
\hline & \multicolumn{2}{c}{$\begin{array}{c}\text { Component matrix } \\
\mathrm{PC} 1\end{array}$} & $\mathrm{PC} 2$ & \multicolumn{2}{c}{ Rotated component matrix } \\
Variables & $(73.584 \%)$ & $(13.692 \%)$ & $\mathrm{PC} 1(73.584 \%)$ & $(13.692 \%)$ \\
\hline $\mathrm{Fe}$ & $\mathbf{0 . 9 7 1}$ & & $\mathbf{0 . 9 5 3}$ & \\
$\mathrm{Ni}$ & $\mathbf{0 . 9 6 2}$ & & $\mathbf{0 . 9 6 1}$ & \\
$\mathrm{Cr}$ & $\mathbf{0 . 9 5 3}$ & & $\mathbf{0 . 9 4 7}$ & \\
$\mathrm{Co}$ & $\mathbf{0 . 9 3 2}$ & & $\mathbf{0 . 9 5 9}$ & \\
$\mathrm{As}$ & $\mathbf{0 . 8 9 7}$ & & $\mathbf{0 . 7 8 9}$ & 0.427 \\
$\mathrm{Cu}$ & $\mathbf{0 . 8 7 8}$ & & $\mathbf{0 . 8 4 9}$ & \\
$\mathrm{Zn}$ & $\mathbf{0 . 8 1 8}$ & 0.454 & $\mathbf{0 . 5 3 1}$ & $\mathbf{0 . 7 7}$ \\
$\mathrm{Cd}$ & $\mathbf{0 . 7 0 8}$ & & $\mathbf{0 . 5 3 2}$ & $\mathbf{0 . 5 2 1}$ \\
$\mathrm{Pb}$ & 0.481 & $\mathbf{0 . 8 6 4}$ & & $\mathbf{0 . 9 8 8}$ \\
\hline
\end{tabular}

Note: PC: Principal component; Percentages in brackets are explained contribution of principal component to the total eigenvalue's variance after varimax rotation.

Variables (PC1 and PC2: 87.276\%) after Varimax rotation

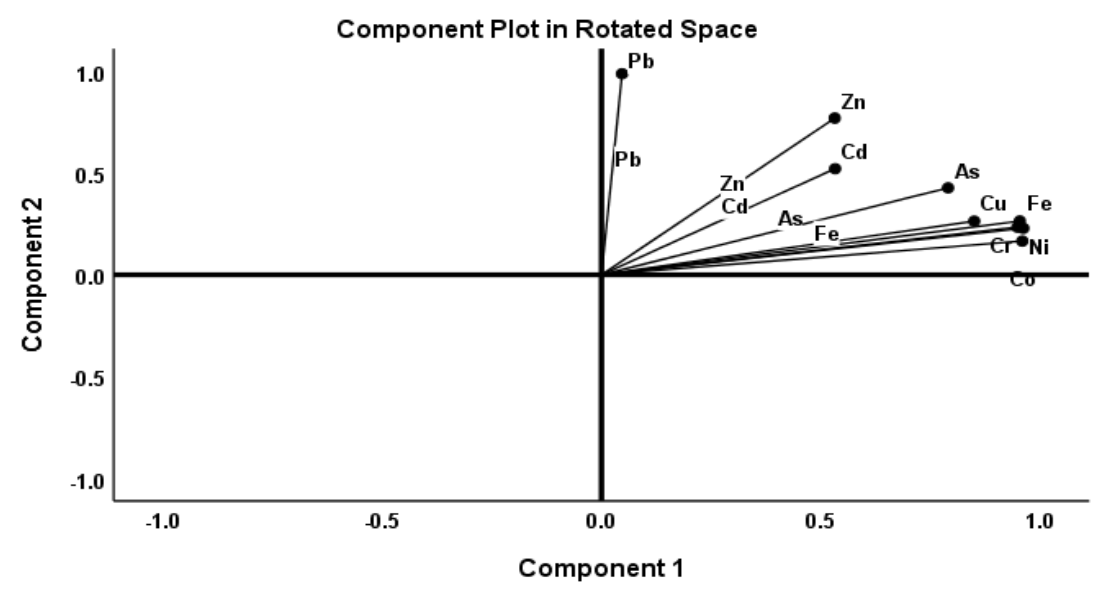

Figure 2: A two-dimensional component plot in rotated space of heavy metals. 

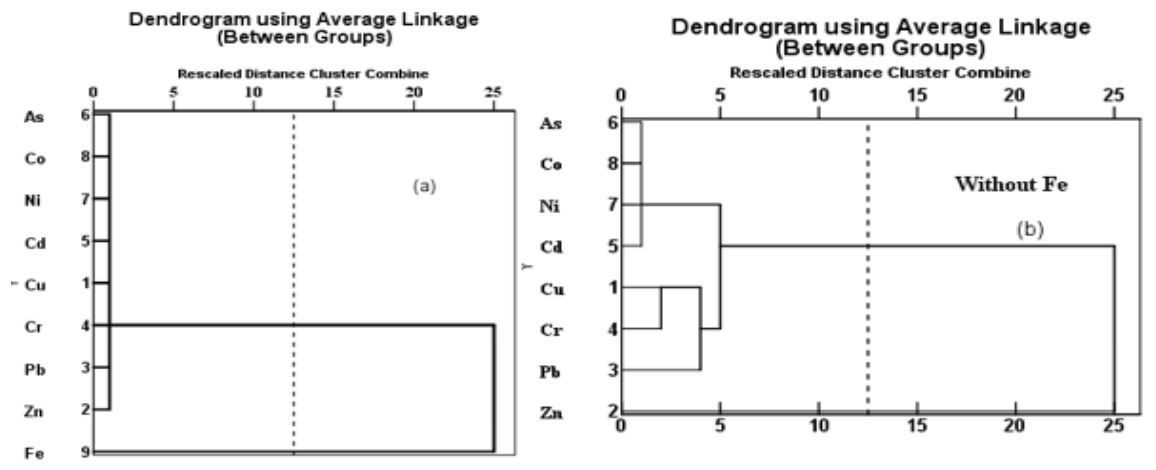

Figure 3: Hiererchical clustering dendrogram of heavy metals (a) with $\mathrm{Fe}$ and (b) without $\mathrm{Fe}$ metal.

\section{Heavy metals contamination levels along Dar es Salaam Harbour channel}

Pollution assessment indices were used to establish heavy metal contamination levels in sediments along Dar es Salaam harbour channel. Heavy metals had an overall enrichment order of $\mathrm{Cd}>\mathrm{Pb}>\mathrm{Zn}>\mathrm{As}>\mathrm{Cu}$ $>\mathrm{Cr}>\mathrm{Co}>\mathrm{Ni}$, whereas $\mathrm{Cu}, \mathrm{Cr}$, $\mathrm{Co}$ and $\mathrm{Ni}$ had low enrichments. Arsenic showed moderate enrichments in the southern part of the harbour but low enrichment at the harbour area and offshore. Highest enrichments were for $\mathrm{Cd}, \mathrm{Pb}$ and $\mathrm{Zn}$ (Figure $3 \mathrm{a}, \mathrm{b}, \mathrm{c}$ ), respectively. Severe Cd enrichments $(5<\mathrm{EF}$ $<20)$ were encountered in most of the sediments and very high enrichments $(20<$ $\mathrm{EF}<40)$ in sediments from sampling stations G 2, 18, 33. Most of the sampling stations $(50 \%)$ were moderately enriched with $\mathrm{Pb}(2<$ $\mathrm{EF}<5$ ), while sampling stations G 15, 18, and 20 were severely enriched with $\mathrm{Pb}$. Zinc was moderately enriched in $26 \%$ of the sampling stations (G-2, 3, 5, 8, 13, 14, 18, 21, and 22) and severely enriched in sampling station G-18 and 20.

The observed enrichment levels correspond to Mihale $(2017,2019)$ and Sawe et al. (2019), who observed moderate to severe enrichments for $\mathrm{Zn}$, $\mathrm{As}, \mathrm{Cd}$ and $\mathrm{Pb}$ at Mtoni Estuary upstream of the harbour channel and moderate enrichments of $\mathrm{As}, \mathrm{Cd}$ and $\mathrm{Pb}$ at Msimbazi River, respectively. However, Cd showed severe to very high enrichments at the harbour channel as compared to Mtoni Estuary (Mihale 2019) indicating that $\mathrm{Cd}$ is largely transported by suspended particulate matter (Machiwa 2000), which settle in relatively calm water along Dar es Salaam harbour channel. Similarly, sediments from the harbour area had higher $\mathrm{Pb}$ enrichments (moderate to very high), contrary to Msimbazi estuary which had low to moderate $\mathrm{Pb}$ enrichments (Sawe et al. 2019), thus revealing that more $\mathrm{Pb}$ were coming from Mtoni estuary and at the harbour area.

Likewise, most of heavy metals showed low geo-accumulation indices, indicating natural to moderate contamination conditions, except for $\mathrm{Cd}$ which indicated moderate to heavily contaminated sediments along the channel. $\mathrm{Pb}$ indicated moderate to heavy contamination at the harbour area, affirming that much of $\mathrm{Pb}$ contamination was a result of anthropogenic activities at the harbour area. Manoj and Padhy (2014) classified geoaccumulation index (Igeo) as; Igeo $<0$ uncontaminated; $0<$ Igeo $<1$ uncontaminated to moderately contaminated; $1<$ Igeo $<2$ moderately contaminated; $2<$ Igeo $<3$ moderate to heavily contaminated; $3<$ Igeo $<4$ heavily contaminated; $4<$ Igeo $<5$ heavily to extremely contaminated; and Igeo $\geq 5$ extremely contaminated. However, the above contamination assessment relies on a single substance of interest, but assessment of combined contamination of heavy metals was developed by Hakanson (1980) as degree of contamination $(\mathrm{Cd})$, and potential ecological risk index (PERI). 


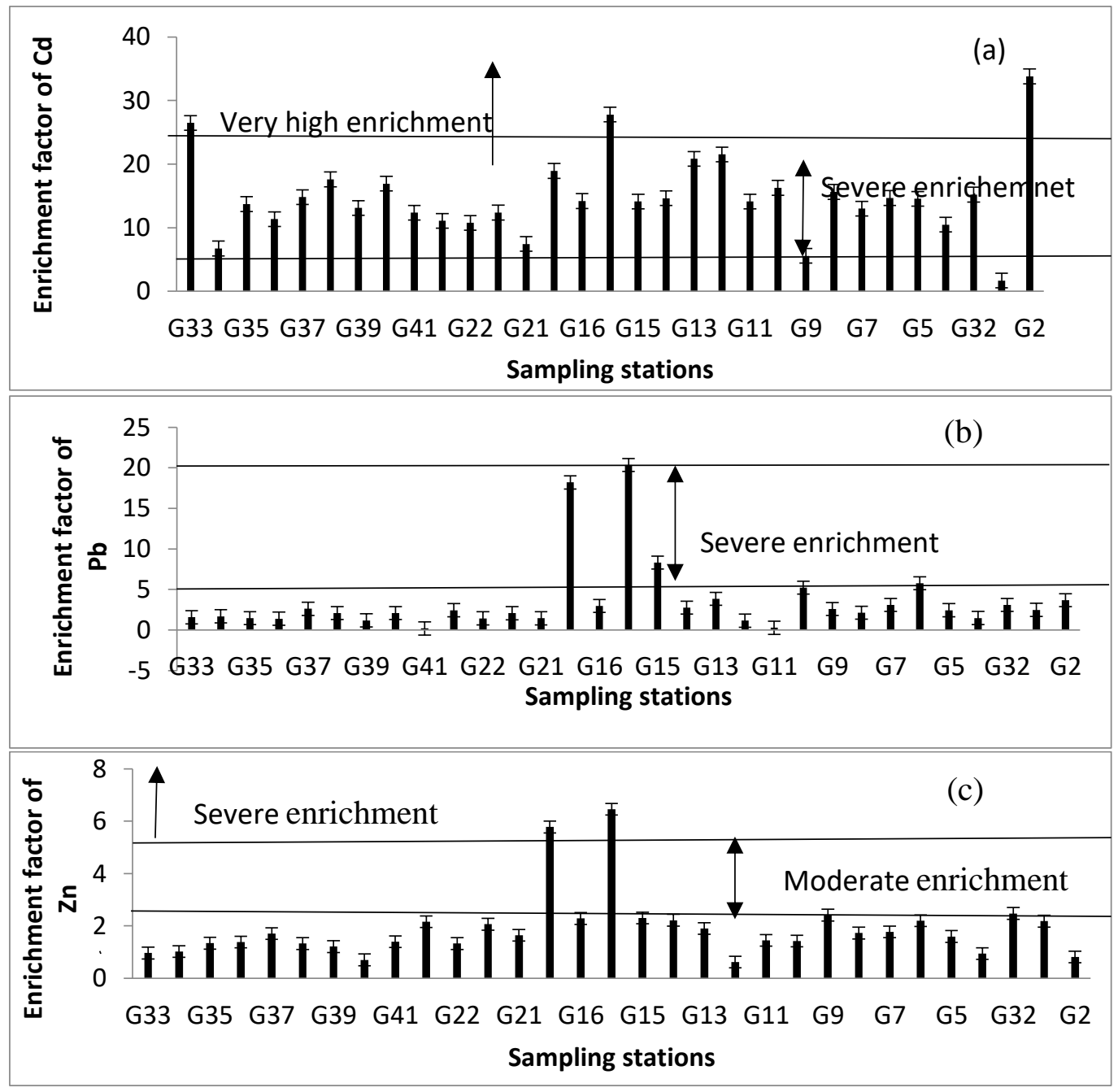

Figure 3: Three heavy metals of high enrichments in sediments along Dar es Salaam harbour channel.

The contamination factors and degree of contamination varied from low to very high contamination conditions. As, $\mathrm{Ni}, \mathrm{Co}$ and $\mathrm{Cr}$ showed low contamination $(\mathrm{CF}<1), \mathrm{Cu}$ and Zn showed low $(0.06 \leq \mathrm{CF} \leq 1.4)$ to moderate $(0.06 \leq \mathrm{CF} \leq 1.98)$ contamination (Figure $4 \mathrm{a}$, b). $\mathrm{Pb}$ had considerable to very high contamination $(0.01 \leq \mathrm{CF} \leq 6.24)$ at the harbour area (Figure 4d). Cadmium on the other hand showed a uniquely high contamination $(0.64 \leq \mathrm{CF} \leq 11.27)$ varying from considerable to very high contamination (Figure 4c). 

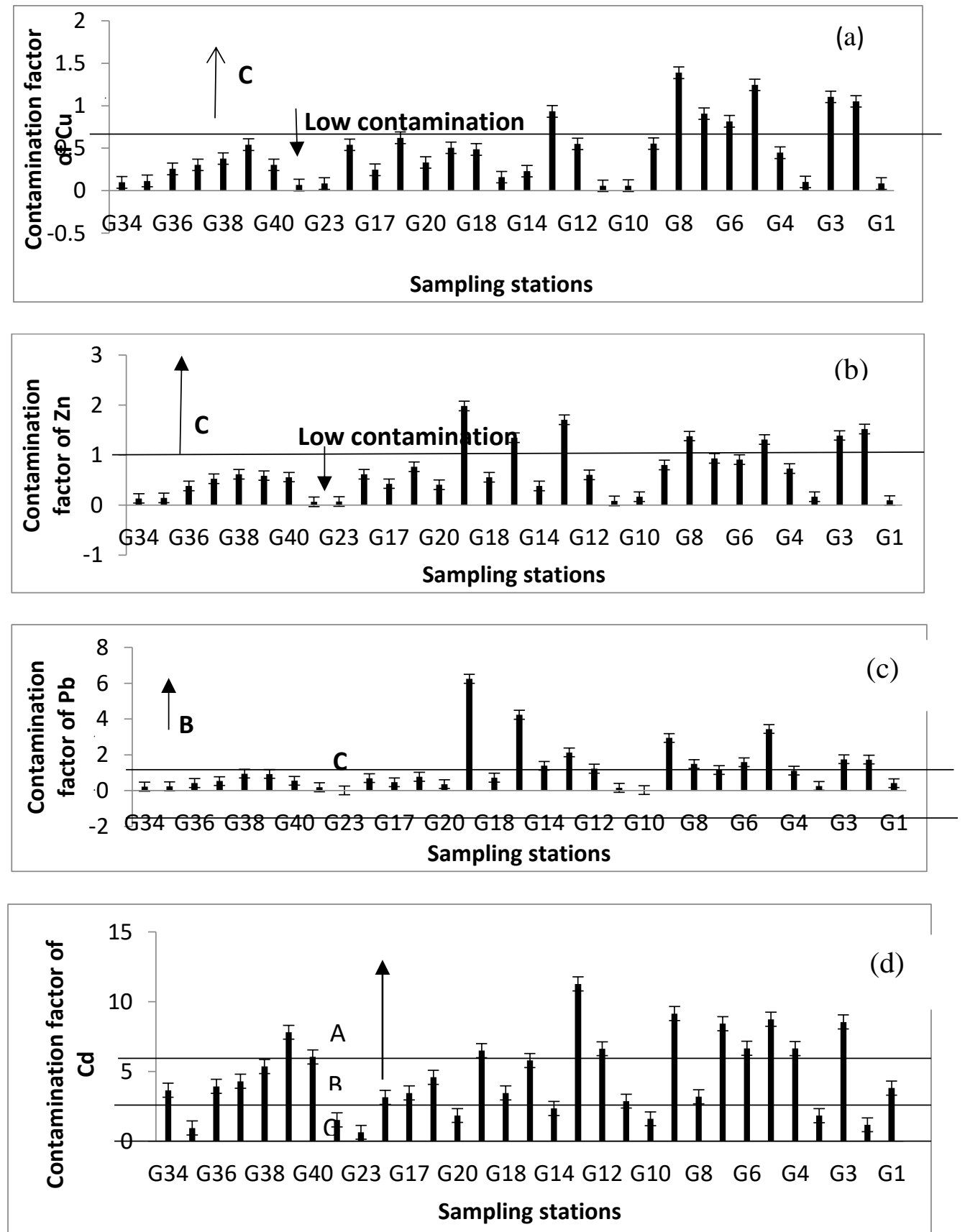

Figure 4: Heavy metals with relatively high contamination factors along Dar es Salaam harbour channel. Note: $\mathrm{A}=$ Very high contamination; $\mathrm{B}=$ Considerable contamination; $\mathrm{C}=$ Moderate contamination .

An overall degree of contamination order was $\mathrm{Cd}>\mathrm{Pb}>\mathrm{Zn}>\mathrm{As}>\mathrm{Cu}>\mathrm{Cr}>\mathrm{Co}>\mathrm{Ni}$, indicating that heavy metals contamination in sediments was largely contributed by $\mathrm{Cd}, \mathrm{Pb}$ and $\mathrm{Zn}$. Degree of contamination varied from low to considerable contamination, $32 \%$ of the sampling stations had low degree of contamination in the northern part of the 
harbour, 39\% had moderate degree of contamination in the southern part of the harbour, while $26 \%$ had a considerable degree of contamination at the harbour area (Figure 5). Contamination factors of almost all metals had strong positive correlation $\left(\mathrm{R}^{2}>0.5\right)$ with the overall degree of contamination except for $\mathrm{Cu}$ (Figure 6).

Severe to very high contamination of $\mathrm{Cd}$ throughout the harbour channel was similarly observed by Manoj and Padhy (2014), Saleh et al. (2018) and Al-Edresy (2019) in estuaries at tropical river of Chottanagpur plateau and Aden coast, Southern Yemen, in which the main sources were from urban anthropogenic activities. Moderate to severe contamination of $\mathrm{Pb}$ at the harbour area ascribed anthropogenic source at the harbour. Moderate to severe contamination of $\mathrm{Zn}$ was observed in the southern part of the harbour channel, however the values were lower than those observed at Mtoni estuary (Mihale 2019). Thus, higher levels of heavy metals in Mtoni estuary influenced the levels of heavy metals downstream at the harbour channel transported by suspended particles (Mrutu et al. 2013, Mihale 2017, Silva et al. 2019).

\section{Ecological risks of heavy metals contamination in surface sediments}

The potential ecological risks index (PERI) was established to ascertain the potential ecological risks of heavy metals in sediments along the harbour channel. The values of PERI varied with sampling stations (Figure 7) and the ecological risk classification ranged from low to high of which $54.8 \%$ of the sampling stations had low ecological risk $(<$ $150), 35.5 \%$ had moderate ecological risk $(150<$ PERI < 300) and $6.5 \%$ high ecological risk $(300<$ PERI < 600) at the harbour area.

Moderate to high potential ecological risks were revealed mainly at the harbour area and the southern part, which were similar areas with high heavy metal contamination factors and degree of contamination. This suggests that most of heavy metals along the harbour channel were from urban anthropogenic activities. However, the overall contamination and potential ecological risks were mainly influenced by the high concentrations of $\mathrm{Cd}$, $\mathrm{Pb}$ and $\mathrm{Zn}$ indicating high inputs of $\mathrm{Cd}, \mathrm{Pb}$ and $\mathrm{Zn}$ in the area. High ecological risks of $\mathrm{Cd}$ and $\mathrm{Pb}$ were similar to that observed by Mihale (2017) at Mtoni estuary showing the potential contribution of Mtoni estuary to contaminate the harbour channel. Moderate to high potential ecological risks of heavy metals in sediments along Dar es Salaam harbour channel threaten the survival of benthic ecosystems and the transfer of heavy metals through bioaccumulation in the food chain to human beings.

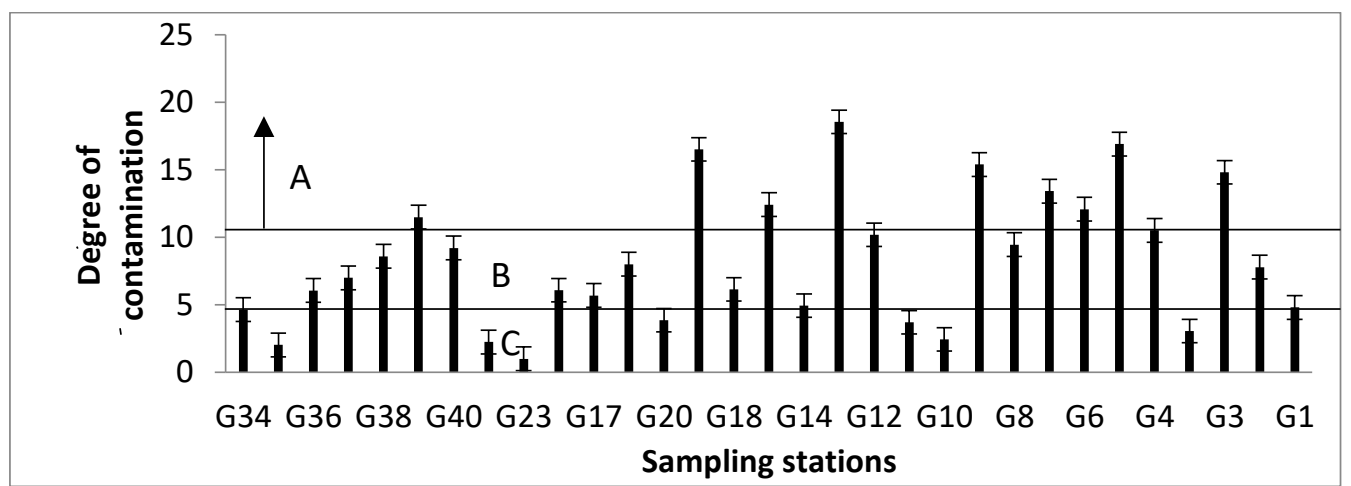

Figure 5: Degree of contamination of heavy metals in the sediments of Dar es Salaam harbour channel. Note: $\mathrm{A}=$ Considerable degree of contamination; $\mathrm{B}=$ Moderate degree of contamination; $\mathrm{C}=$ Low degree of contamination. 

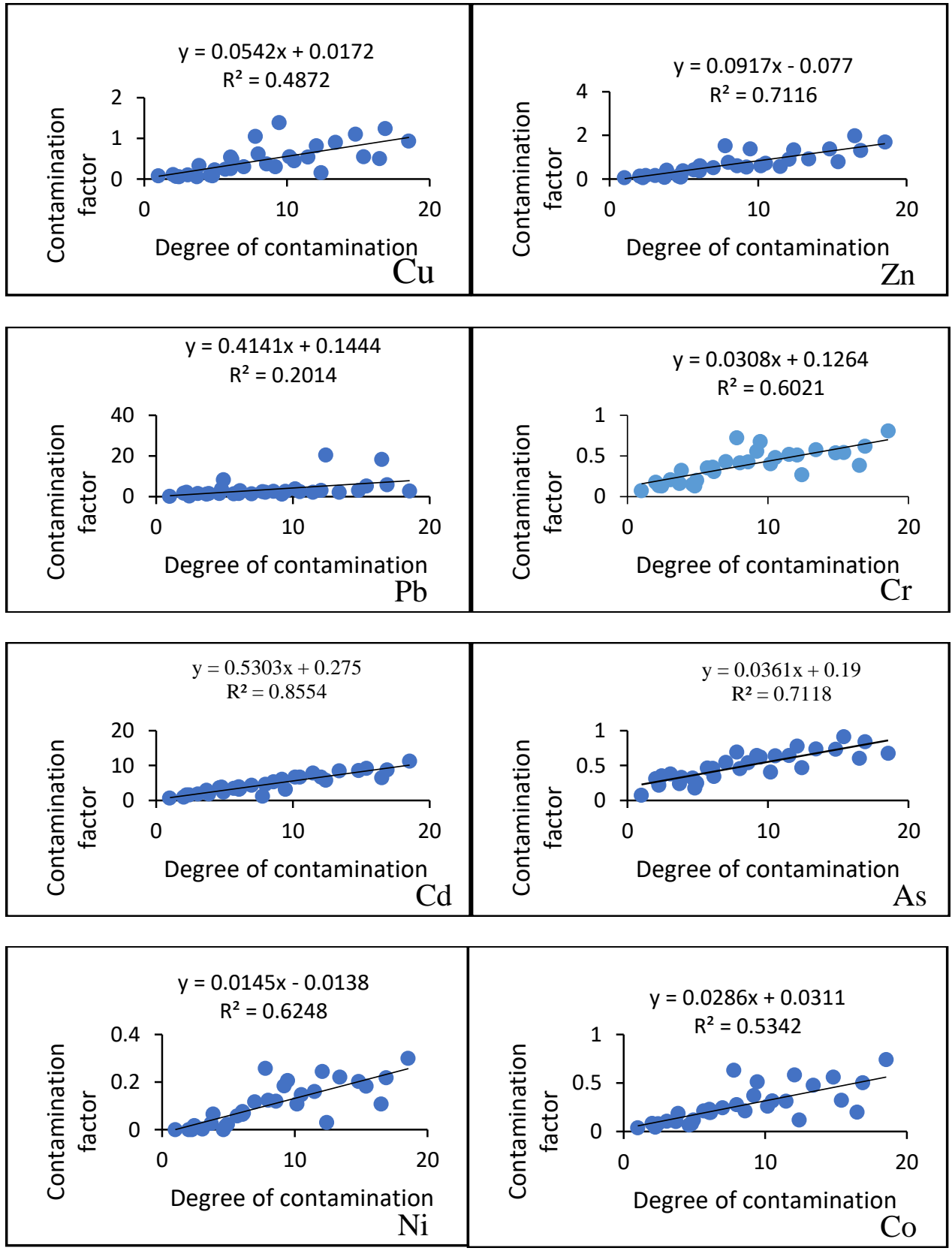

Figure 6: Relationship between contamination factors and degree of contamination. 


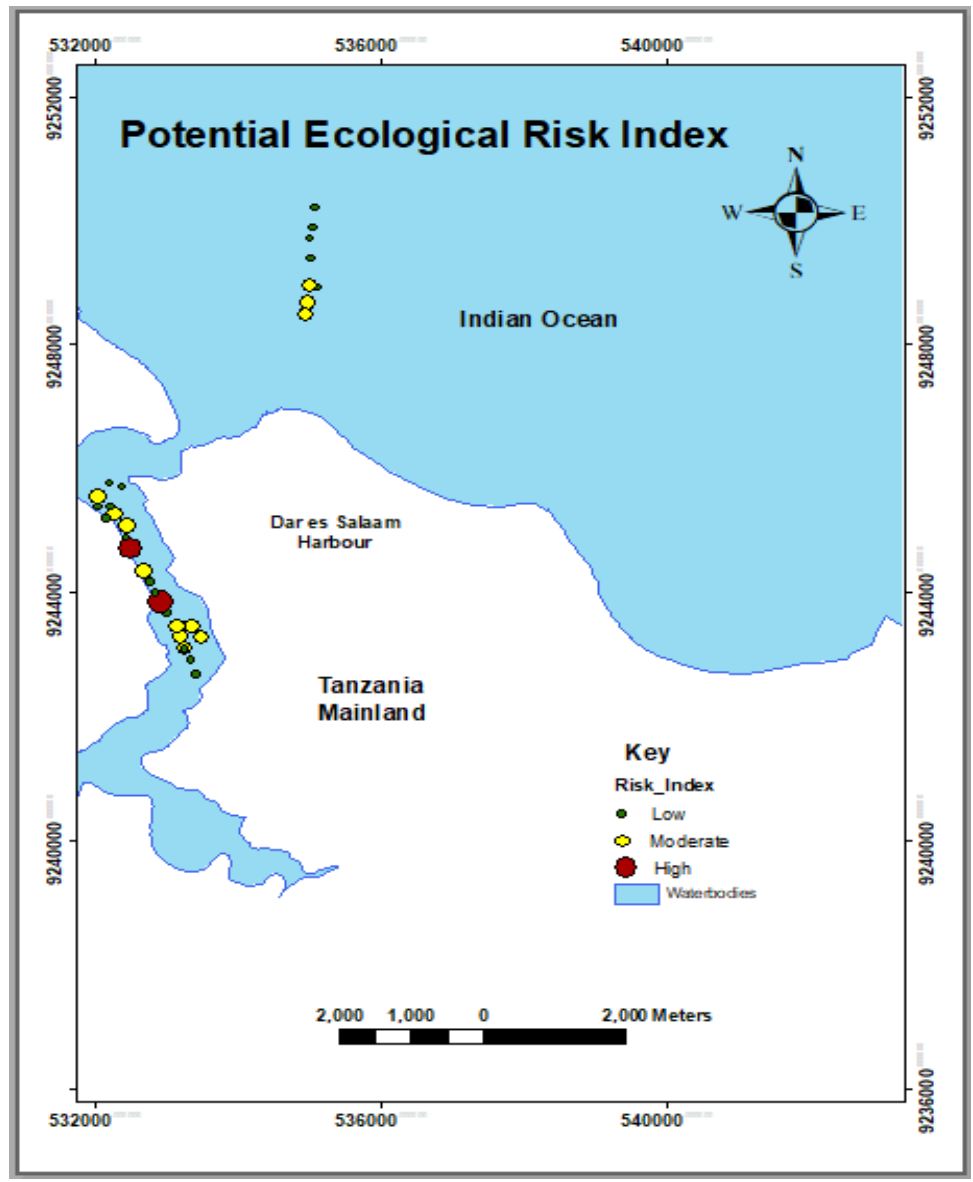

Figure 7: Potential ecological risk status of heavy metals at Dar es Salaam harbour channel.

\section{Conclusion}

Spatial and typological variations of heavy metal contamination in sediments along Dar es Salaam harbour channel provides a contamination status and control criteria in heavy metal point sources. Variations in the degree of contamination and ecological risks of heavy metals give clues of contamination sources which offer pre-requisite contamination information to deal with for heavy metal pollution control. Moderate to considerable degrees of contamination with moderate to high potential ecological risks of heavy metals $(\mathrm{Cd}, \mathrm{Pb}$ and $\mathrm{Zn})$ pose threats to the survival of benthic biota and the ecological sustainability in coastal marine waters of Dar es Salaam coast. These effects may propagate through the food chain to affect human health. This necessitates for a need of anthropogenic contamination control over sediment quality deterioration and the study of toxicity effects of heavy metals to the benthic biota along coastal marine waters in the Western Indian Ocean.

\section{Acknowledgements}

Sincere thanks go to the late Prof. Alfred N.N. Muzuka for financial support in the field work through TECHNITAL Ltd. May his soul rest in eternal peace.

\section{Conflicts of Interest}

Authors declare no conflicts of interest regarding the publication of this paper.

\section{References}

Adeyemi MO, Olusola JA, Akpobasah O, Adidi NE and Shelle ROD 2019 Assessment of heavy metals pollution in sediments from 
Ologe Lagoon, Agbara, Lagos, Nigeria. J. Geosci. Environ. Prot. 7: 61-73.

Addis W and Abebaw A 2017 Determination of heavy metal concentration in soils used for cultivation of Allium sativum L. (garlic) in East Gojjam Zone, Amhara Region, Ethiopia, Cogent Chem 3:1. 1419422.

Al-Edresy MAM, Wasel SO and Al-Hagibi HA 2019 Ecological risk assessment of heavy metals in coastal sediments between AlHaymah and Al-Mokha, south red sea, Yemen. Int. J. Hydrol. 3(2): 159-173.

Bai JH, Cui BS, Chen B, Zhang KJ, Deng W and Gao HF 2011 Spatial distribution and ecological risk assessment of heavy metals in surface sediments from a typical plateau lake wetland. Ecol. Modell 222: 301-306.

Custodio M, Huaraca F, Espinoza C and Cuadrado W 2019 Distribution and accumulation of heavy metals in surface sediment of Lake Junín National Reserve, Peru. Open J. Mar. Sci 9: 33-48.

Darko G, Dodd M, Nkansah MA, Aduse-Poku Y, Ansah E, Wemegah DD and Borquaye LS 2017 Distribution and ecological risks of toxic metals in the top soils in the Kumasi metropolis, Ghana. Cogent Environ. Sci. 3(1): 1354965.

den Besten PJ and Munawar M 2005 Ecotoxicological Testing of Marine and Freshwater Ecosystems. Emerging Techniques, Trends, and Strategies. CRC Press. Taylor and Francis Group 6000 Broken Sound Parkway NW, Suite 300. Boca Raton, FL33487-2742 Boca Raton London.

EPA 2002 Methods for Measuring the Toxicity and Bioaccumulation of Sediment-associated Contaminants with Freshwater Invertebrates ( $2^{\text {nd }}$ Edition). Office of Research and Development. Washington DC 20460.

EPA 2018 Hazardous Waste Test Methods/SW846 Method 6010D for Inductively Coupled Plasma-Optical Emission Spectrometry protocol. $5^{\text {th }}$ Revision.

Goh BPL, Lai CH, Tan LT, Yap NWL and Dissanayake A 2014 Handbook of marine ecotoxicology techniques. National Institute of Education, Nanyang Technological University $\&$ National Parks Board. Singapore.

Hakanson L 1980 An ecological risk index for aquatic pollution control. A Sedimentological Approach. Water Res. 14: 975-1001.

Hogstand C and Haux C 1991 Binding and detoxification of heavy metals in lower vertebrates with reference to metallothionein. Compar. Biochem. Physiol. C. 100 (1-2): 137214.
Keshavarzi A and Kumar V 2020 Spatial distribution and potential ecological risk assessment of heavy metals in agricultural soils of Northeastern Iran. J. Geol. Ecol. Landscapes 4(2): 87-103.

Kowalska JB, Mazurek R, Gasiorek M and Zalesk T 2018 Pollution indices as useful tools for the comprehensive evaluation of the degree of soil contamination. A review. Environ. Geochem. Health. 40: 2395-2420.

Krampah F, Nyarko SY, Danlogo K and Sanful P 2019 Application of Pollution indices in the assessment of heavy Metal contamination of surface sediments of River Bonsa, Ghana. $J$. Geosci. Environ. Prot. 7: 176-189.

Lee J, Kwon B, Kim B, Noh J, Hwang K, Ryu J, Park J, Hong S and Khim JS 2019 Natural and anthropogenic signatures on sedimentary organic matters across varying intertidal habitats in the Korean waters. Environ. Int. 133: 105-166.

Liu CW, Lin KH and Kuo YM 2003 Application of factor analysis in the assessment of groundwater quality in a Blackfoot disease area in Taiwan. Sci. Total Environ. 313: 77-89.

MacDonald DD 1994 An approach to the assessment of sediment quality in Florida coastal waters. Vo 1. Development and Evaluation of Sediment Quality Assessment Guidelines. Florida Department of Environmental Protection. Office of Water Policy. 3900 CommonwealthBoulevard, MS46. Tallahassee, Florida. USA.

Machiwa JF 2010 Coastal marine pollution in Dar es Salaam (Tanzania) relative to recommended environmental quality targets for the Western Indian Ocean. West. Indian Ocean J. Mar. Sci. 9 (1): $17-30$.

Machiwa JF 2000 Heavy metals and organic pollutants in sediments of Dar es Salaam harbour prior to dredging in 1999. Tanz. J. Sci. 26: 29-45.

Mahugija JAM and Sheikh HM 2018 Status of selected heavy metals dispersion from top soil in and around automobile workshop areas in Zanzibar Municipality, Tanzania. Tanz. J. Sci. 44(1): 12-23.

Manoj K and Padhy PK 2014 Distribution, enrichment and ecological risk assessment of six elements in bed sediments of a tropical river, chottanagpur plateau: a spatial and temporal appraisal. J. Environ. Prot. Sci. 5: 1419-1434.

Mihale MJ 2019 Multivariate assessment of metal contamination in mtoni sedimentary environment, Tanzania. Tanz. J. Sci. 45 (2): 158-172. 
Mihale MJ 2017 Environmental health risks due to anthropogenic metals in mtoni estuary ecosystem and its environs, Tanzania. Huria Journal. 24 (1): 1-24.

Mrutu A, Nkotagu HH and Luilo GB 2013 Spatial distribution of heavy metals in Msimbazi River mangrove sediments in Dar es Salaam coastal zone, Tanzania. Int. J. Environ. Sci. 3(5): 1641-1655.

Mwakisunga B, Machiwa JF and Pratap HB 2020 Assessment of sediment and benthic macrofauna distribution at Dar es Salaam Harbour channel. J Geosci. Environ. Prot. 08(03): 133-147.

Saleh SMK, Amer AT and Al-Alawi A 2018 Potential ecological risk of heavy metals in surface sediments from the Aden coast, Southern Yemen. J. Environ. Sci. Toxicol. Food Technol. 12 (10): 42-55.

Sana'a O 2015 Application of geoaccumulation index and enrichement factors on the assessment of heavy metal polllution along Irbid/zarqa highway-Jordan. J. Appl. Sci. 15: 1318-1321.

Sawe SF, Shilla DA and Machiwa JF 2019 Assessment of enrichment, geo-accumulation and ecological risk of heavy metals in surface sediments of the Msimbazi mangrove ecosystem, coast of Dar es Salaam, Tanzania. Chem. Ecol. 35(9): 835-845

Silva YJAB, Cantalice JRB, Singh VP, Nascimento CWA, Wilcox BP and Silva YJAB 2019 Heavy metal concentrations and ecological risk assessment of the suspended sediments of a multi-contaminated Brazilian watershed. Acta Sci. Agron. 41(1). 42620.

Silva FBV, Nascimento CWA, Araújo PRM, Silva LHV and Silva RF 2016 Assessing heavy metal sources in sugarcane Brazilian soils: an approach using multivariate analysis. Environ. Monit. Assess. 188(8): 457.

Sivakumar S, Chandrasekaran A, Balaji G and Ravisankar R 2016 Assessment of heavy metal enrichment and the degree of contamination in coastal sediment from South East Coast of Tamilnadu, India. J. Heavy Met. Tox. Dis. 1(2): 11-19.

Soliman NF, Nasr SM and Okbah MA 2015 Potential ecological risk of heavy metals in sediments from the Mediterranean coast, Egypt. J. Environ. Health Sci. Eng. 13(70): 112.

Turekian KK and Wedepohl KH 1961 Distribution of the elements in some major units of the Earth's CRUSt. Geo. Soc. Am. Bull. 72: 175192.

UNEP and CSIR 2009 Guidelines for the Establishment of Environmental Quality Objectives and Targets in the Coastal Zone of the Western Indian Ocean (WIO) Region. WIO-LaB Technical Report Series No. 01/2009, United Nations Environment Programme (Nairobi Convention Secretariat), Kenya, Nairobi. 